\title{
Fiscal Decentralization in Somaliland: Challenges and the Way Out
}

\author{
Abdiwahab Ali Garad ${ }^{1 *}$ Khalid Ahmed Abdi ${ }^{2}$ \\ 1. Hargeisa School of Economics, University of Hargeisa, Hargeisa, Somaliland \\ 2. Hargeisa School of Economics, University of Hargeisa, Hargeisa, Somaliland \\ * E-mail of the corresponding author: abdiwahabgarad@yahoo.com
}

\begin{abstract}
After regaining its independence, Somaliland made a unitary system of governance in which the constitution establishes central government with regional and local governments. where Local governments provide basic services as per their capacity. The number of districts, their hierarchy, and boundaries were to be [and are still to be] defined by law. Donors and UN Agencies introduced Joint Program for Local Governance and Decentralization (JPLG) which has been operational in Somaliland since 2008, supporting decentralization. Nonetheless, decentralization efforts in Somaliland, particularly those pertaining to fiscal affairs face many challenges. The main aim of this study is to explore key fiscal decentralization challenges and available options for a better fiscal decentralization system. There is unnecessary increase of districts based on tribal political motivations many of them with limited taxable economic base and their dependency on electoral districts in elections. Subsidy allocations to local governments are not based on assessed physical and socioeconomic factors and have not been predictable nor fairly distributed. Districts with custom posts receive municipal tax revenue which raises local government budget over comparable districts. unless addressed with equalization funds such budget inequality among local governments in the process of decentralization will have a negative disparity in the services provided and livelihoods among districts. Other challenges include poor legal framework and limited institutional capacity. However, Somaliland should rethink the type of decentralization to adopt, review policies and regulatory frameworks applied to subnational governments to reflect best practices.
\end{abstract}

Key Words; Fiscal Decentralization, Somaliland, local governments/districts.

DOI: $10.7176 / \mathrm{PPAR} / 10-6-09$

Publication date:June 30th 2020

\section{Introduction}

Decentralization and local government reforms became popular in development trends and practices in the 1990s (Hartmann, 2008). Many sources defined that decentralization involves the transfer of power, responsibilities, and finance management from the central government to sub-national levels of government.

According to Kulipossa, (2008) decentralization takes various forms across countries, majorly due to variances in cultures, institutions, and fiscal characteristics. However, all remain susceptible to similar problems that undermine successful implementation.

As a subset of decentralization, fiscal decentralization refers to the empowerment of subnational governments in terms of tax collection and spending (Oommen, 2006) and it remains important under public finance theory (Oates, 2006). Furthermore, Theorists of fiscal federalism argue that appropriate functions and finance of local governments makes efficiency that maximizes the welfare of local communities (Bird, 1995), decentralizing fiscal powers to subnational governments has been a response to efforts demanding democratization (Defere, 2018). Nevertheless, the economic rationale is not easy as assumed under different concepts of public goods (Oates, 2006). Fiscal decentralization is seen as the easiest dimension of decentralization which highly proliferated in the 1990s. However it has been witnessed that central government agencies remain reluctant to decentralize to subnational governments. On the other hand, subnational governments are not politically, administratively, and technically prepared to use additional given resources (Smoke, 2000).

\subsection{Theoretical Underpinnings}

Apart from the approach taken in implementing decentralization, a major stamping block is a modality chosen; deconcentrating, delegation, or devolution. (Bernard Dafflon, Thierry Maddies, 2013), while the issue of appropriate fiscal assignment between different levels of government has been widely debated (Young, 2002).

Throughout the literature, arguments in favor of decentralization built on economic efficiency and reduction of 
regional income disparity. According to Hartmann (2008), decentralization mitigates conflicts as it allows for political participation and inclusion, improves national integration by harmonizing policies and service delivery. (Elmi, 2014) also indicated internal drivers for decentralization in Somalia to be grievance from the periphery, mistrust between clans, whereas donor community poses as an external driver.

However, decentralization may post a threat to fiscal discipline with potential macro-fiscal risks (Hobdari et al., 2018), other arguments indicate fiscal decentralization leads to inequities because of imbalances in sources of taxes and disparity in regions (Alam, 2019). There are also risk of whether decentralization of fiscal powers in terms of expenditure and taxing can potentially undermine fiscal policy and monetary policy which are pillars of macroeconomic management (Defere, 2018).

The issue of reforming fiscal relations between levels of government has been an important fiscal policy for most African states where many of them have decentralized delivery of some goods and services(Young, 2002).

Smoke (2012) critically argued some countries with political commitment did not reach decentralization system they thought about and proposed to reflect upon decentralization prerequisites as a basic element.

Ethiopia and Kenya are among the countries that took decentralization reforms that devolved power, responsibilities, and resources from central government to subnational governments. Such decentralizations in these countries are underpinned by constitutional amendment. For Ethiopia there were two waves of decentralization reforms, one from federal government to regional government, and onther from regional governments to districts (known as wareda) (Sullivan \& Dutkowsky, 2013)

The IMF listed reforms in Ethiopia, Nigeria, and South Africa as the most advanced fiscal decentralization in subSaharan Africa, according to their share of expenditure at subnational governments (Hobdari, Nguyen, Dell'Erba, \& Ruggiero, 2018). However, Alam (2019) argued local government in Ethiopia are not practicing fiscal decentralization as they largely use monetary funds on recurrent costs.

\subsection{Research Methods}

Though fiscal decentration -aside from the theoretical conceptualizations that are available in literature- is borne to various physical challenges, the post-conflict nature of Somaliland that is characterized by total ruin institutional capabilities and structures that remain under construction for the entirety of its short lifespan pose as a new theoretical frontier that is yet to be explored. Its is quite unknown how the new political settlement of Somaliland (post independence from Somalia and the United Kingdom) shaped the theoretical governance structural standards that are available in the international arena. Nevertheless, this papers' major outlook is to analyze and understand the state of fiscal decentralizations in Somaliland and the major challenges that are to be expected when implementing a wide scale decentralization in a post conflict arena, and finally, the remedies and recommendations required for a healthier implementation strategies and how the identified loop holes that were previously un accounted can be filled.

Using different types of data collection tools, the study covered decentralization sector ministries, local governments implementing decentralized services under the program of JPLG, Association of Local Governments Authorities (ALGASL), technical staff in decentralization reforms, respective local staff of involved UN Agencies based in Hargeisa.

Targeted key informants including mayors, director generals of Ministry of Finance, Ministry of Interior, Ministry of Public Works Land and Housing, Ministry of Transport and Roads Development, Director of Association for Local Governments for Somaliland (ALGASL) with prepared closed and open-ended questionnaires. The Researchers also conducted Focus Group Discussions for technical staff from concerned institutions (ministries, local governments, UN agencies) to deeply discuss the subject matter of the study. Furthermore, desk reviews of available material, including white papers and data from implementing agencies and concerned ministries formed the bulk of the structural backing required to cement conceptual understandings and analytical emphases for the study.

\subsection{Overview of Somaliland Fiscal Decentralization}

Like any other unitary government, the constitution of Somaliland does not empower subnational governments but lays subordinate level of governance. While federal governments have subnational governments empowered by a constitution. After regaining its independence, Somaliland restored the state institutions including subnational authorities. The Government is in three-tier- formation design, the central government, regions, and local governments. The structure of the Government as set by the Somaliland constitution is 'regions and districts in which the number, their hierarchy and boundaries are described by law. 
The success of development agendas and democratic governance depends on participation of local communities in decision making in regards to the issues directly affecting their lives (Kim, 2019). The idea of decentralizing basic social services to local governments has been constitutional in Somaliland, depending upon their ability to do so. However, these basic services are usually provided by central government ministries and agencies for reasons including limited capacity and fiscal constraints in local governments.

Decentralization of many developing countries is characterized by administrative and fiscal challenges in relation to revenue raising and expenditure authority (Haas, 2017), similarly Somaliland central government transfers different types of funds to local governments, namely; local governments subsidy, funds for decentralized services of education and health which are pilot in number of districts, and Local Development Fund as part of Joint Program for Local governance. These intergovernmental transfers as part of fiscal decentralization face tremendous institutional challenges. Both local governments and central government institutions are cribled by barriers in pursuing activities related to funds transfers.

Joint Program for Local Governance and Decentralization (JPLG) has been working in Somaliland since 2008 supporting local governments in capacity building, development and governance, and is supported by donors including the European Commission, Denmark, Norway, Sweden and UK Aid. JPLG currently works closely with eight local governments (Hargeisa, Gabiley, Borama, Berbera, Sheikh, Burao, Odweine and Zaylac) through the respective Central Government ministries for promoting capacity of local governments to provide equitable services to communities (Simkin, 2016). The program placed emphasis on supporting local governments reforms and capacity building, organizational structures, accountability, regulations and policies (UNDP, C2 Annual Report). With the help of this program decentralization policy has been developed in 2013 and approved by the cabinet in 2014. The strategy pointed out the presence of reluctance and confusion of central government ministries over the roles and responsibilities of central government ministries and local governments.

Decentralization is fragmented across three different reform processes; the Public Financial Management, Civil Service, and Decentralization (Somaliland Fiscal Decentralization Strategy, 2016). Fiscal Decentralization Strategy was set by the JPLG with Ministry of Interior whereas PFM Strategy which is supported by the World Bank has fiscal decentralization parts for local governments.

\subsection{Challenges and Shortcomings for Sound Fiscal Decentralization System}

\subsection{Proliferation of Appointed Districts and Interdependency Among Local Governments}

Though constitution clearly stipulated that local governments provide basic services according to their ability, the central government has always been providing goods and services mainly due to fiscal constraints and lower institutional capacity of local governments. The Constitution of Somaliland sets structures of government in regions and districts in which the hierarchy and boundaries shall be described by law. As per Law No. 23/2002, upgrading and downgrading of districts is by law dependent on assessment of certain known criteria but it has never been enforced in such a manner.

This table below shows the number and different grades of districts in the Law No. 23/2002.

Table 1 number and different grades of districts in Law No. 23/20002002

\begin{tabular}{|l|l|l|l|l|l|l|}
\hline Region & $\begin{array}{l}\text { Grade } \\
\text { districts }\end{array}$ & $\begin{array}{l}\text { Grade } \\
\text { districts }\end{array}$ & $\begin{array}{l}\text { Grade } \\
\text { districts }\end{array}$ & $\begin{array}{l}\text { Grade } \\
\text { districts }\end{array}$ & Dotal \\
\hline Awdal & 1 & 1 & 2 & 1 & 5 \\
\hline Marodijeh & 2 & 0 & 2 & 6 & 10 \\
\hline Sahil & 1 & 0 & 1 & 3 & 5 \\
\hline Togdher & 1 & 2 & 0 & 3 & 6 \\
\hline Sool & 1 & 0 & 3 & 2 & 6 \\
\hline Sanag & 1 & 2 & 3 & 4 & 10 \\
\hline Total & 7 & 5 & 11 & 19 & 42 \\
\hline Percentages & $16.6 \%$ & $11.9 \%$ & $26.2 \%$ & $45.2 \%$ & $100 \%$ \\
\hline
\end{tabular}

Source: (Mal, 2017)

23 districts of grade A, B, and C are known as electoral districts due to their district council being appointed by democratic vote. There are 19 grade D districts in the Law No. 23/2002 which require border demarcations to become electoral districts but now are under the authority of the Minister of Interior who appoints mayor/chairman, 
deputy, and district executive secretaries for them.

Beyond these 19 grade D districts in the law, there have been a growing number of appointed districts by subsequent presidents in Somaliland that add up to 59 grade D districts (bringing the new total of grade D districts in the newly amended version of law $23 / 2002$ to 78 districts). The appointment of these new districts that break away from their parent district have almost been politically motivated and was primarily founded on tribalism and tribal political settlement boundaries.

Table 2; number and different grades of districts in the Law No. 23/2019 (new version)

\begin{tabular}{|l|l|l|l|l|l|}
\hline Region & $\begin{array}{l}\text { Grade A } \\
\text { districts }\end{array}$ & $\begin{array}{l}\text { Grade } \\
\text { districts }\end{array}$ & $\begin{array}{l}\text { Grade C } \\
\text { districts }\end{array}$ & $\begin{array}{l}\text { Grade } \\
\text { districts }\end{array}$ & Total \\
\hline Awdal & 1 & 1 & 2 & 8 & 12 \\
\hline Marodijeh & 2 & 0 & 2 & 15 & 19 \\
\hline Sahil & 1 & 0 & 1 & 6 & 8 \\
\hline Togdher & 1 & 2 & 0 & 19 & 22 \\
\hline Sool & 1 & 0 & 3 & 17 & 21 \\
\hline Sanag & 1 & 2 & 3 & 13 & 19 \\
\hline Total & 7 & 5 & 11 & 78 & 101 \\
\hline Percentages & $6.9 \%$ & $4.95 \%$ & $10.89 \%$ & $77.23 \%$ & $100 \%$ \\
\hline
\end{tabular}

Law 23/2019

These grade $\mathrm{D}$ districts are independent as well as symbiotic on their electoral parent district (A,B, or C); they are autonomous from the management of its main electoral district in terms of taxes and management however they are part of the main (parent) district during elections. These small districts are unlikely to cover recurrent costs and deliver social services because of low taxable economic base which consequently bring about administrative cost burdens. These numerous grade $\mathrm{D}$ districts are operational but the newly approved law of local governments proposed that they should only be approved upon receiving positive feedback from assessment and after charting border demarcations.

Programs in JPLG such as decentralized services of education and health, and the Local Development Fund (LDF) projects, are primarily based on electoral districts which again notionally encompass the newly break-away districts. Some of the Mayors of these electoral districts sometimes don't consider rural peripheries- where major break-away districts are situated- due to their claim independent of and do not collect tax revenues due the presence of a ministry appointed mayor.

throughout the previous decade prior to the decentralization efforts, two parallel major phenomena took precedence over the local governments' contexts. Firstly, many local governments experienced increased fiscal positions in terms of raises to their tax base. Re-urbanizations that were brought by the national nation rebuilding strategies and the peace process that successfully reoriented the country to mass de-militarization and democratization process, culminated to the increments of urban dwellers population, hence also increase the tax collected by the local governments. However, all legal regulatory frameworks that were to define the roles and responsibilities of local governments had a shallow and vague description of functional assignments and responsibilities. Creating a gap in the roles assigned to the local council while tax revenues rose up. As per this logic, improvement in districts fiscal space and legal gap caused major community demands to concentrated around a narrow part of the wider municipal responsibilities such as sanitation, roads and infrastructure, but majority of basic services such as education and health were neglected and are still in the void accountability.

\subsection{Intergovernmental Fiscal Transfers; Current Complications and Future Consequences}

In a decentralized budget,districts are often characterized by responsibility-resource gap that is to be financed by higher level of government (central or federal) bridging the gap with additional transfers such as additional grants, formula-based grant etc (Bernard Dafflon, Thierry Maddies, 2013). In Somaliland, Government allocates 12.5\% of custom duty (known as subsidy) for local governmentsIts introduction dates back to early years of state building where there were check points taking taxes in almost every district. When these checkpoints were removed, it was decided to budget this percentage and distribute to local governments based on assessment made at that time based on number of shipped trucks destined to each local government. At that time, this allocation was made by law $12 / 2000$ stated only seven districts with their allocated percentages; Hargeisa (51.26\%), Burao (21.39\%), Gabiley 
(9.87\%), Borama (9.86\%), Sheikh (3.75\%), Seyla (2.18\%), Baki (1.69\%), nevertheless, these allocations went through changes by different Ministers of Interior.

Table 3 Comparison of subsidy allocation in law 12/2000 and current practice

\begin{tabular}{|l|l|l|l|}
\hline Local government & Grade & Law 12/2000 & Current practice \\
\hline Hargeisa & A & $51 \%$ & $30 \%$ \\
\hline Burao & A & $21 \%$ & $12 \%$ \\
\hline Gabilay & A & $10 \%$ & $6 \%$ \\
\hline Borama & A & $10 \%$ & $6 \%$ \\
\hline Berbera & A & $0 \%$ & $5 \%$ \\
\hline Sheikh & C & $4 \%$ & $2 \%$ \\
\hline Zaila & B & $2 \%$ & $1 \%$ \\
\hline Baki & C & $2 \%$ & $1 \%$ \\
\hline Odweine & B & $0 \%$ & $1 \%$ \\
\hline Other Grade A & A & $0 \%$ & $17 \%$ \\
\hline Other Grade B & B & $0 \%$ & $2 \%$ \\
\hline Other Grade C & C & $0 \%$ & $7 \%$ \\
\hline Grade D & D & $0 \%$ & $14 \%$ \\
\hline $\begin{array}{l}\text { Other D (unapproved by } \\
\text { parliament }\end{array}$ & D & $0 \%$ & $0 \%$ \\
\hline Total & & $100 \%$ & $100 \%$ \\
\hline Sorce Mnsty of & & \\
\hline
\end{tabular}

Source: Ministry of Interior, 2018

The National Decentralization Policy approved by Somaliland cabinet in 2014 outlines that "Intergovernmental Fiscal Transfers: The determination of intergovernmental transfers will be based on objective and transparent criteria and consideration of the differences in the classification of the local government, geographic and physical factors, populations, and socio-economic conditions". The intergovernmental fiscal transfer or Subsidy (locally known as Kabka) has never been based on known factors and eligible assessment criteria for allocations. Subsidy is also highly unpredictable, which is detrimental to local governments early planning and financing projects.

The Ministry of Interior appoints a councilor composed of mayor, deputy mayor and executive secretary for districts that have no electoral council. According to Yusuf \& Bradbury (2010) most of these grade D districts largely depend on central government in terms of subsidy and challenged by their lower staff capacity, lack of democratic mandate, and mostly are not self-sustaining due to their inadequate taxable economic base. Through this study almost all local governments visited raised concerns about lack of predictability and transfer of subsidy. Similarly, they posed that $50 \%$ of the total subsidy budget has been cut and re-taken by the central government shown as revenue in the national budget.

Besides not being implemented, the newly version of law for Regions and Districts Administration Law No. $23 / 2019$ article 89 (2) states that $12.5 \%$ of the national budget shall be allocated to districts as shown in the following table.

Table 4; Subsidy allocations of law 23/2019

\begin{tabular}{|l|l|l|}
\hline No. & Grade of District & $\begin{array}{l}\text { Allocation } \\
(\text { Percentage } \%)\end{array}$ \\
\hline 1. & Grade A & $6 \%$ \\
\hline 2. & Grade B & $2 \%$ \\
\hline 3. & Grade C & $3 \%$ \\
\hline 4. & Grade D & $1.5 \%$ \\
\hline & $12.5 \%$ \\
\hline
\end{tabular}

Law No. 23/2019 
Another major source of revenue is the municipal tax from customs for districts with custom posts.

Table 5 Districts and Municipal Tax Revenue

\begin{tabular}{|l|l|lr|l|}
\hline Grade & No of districts & $\begin{array}{l}\text { Percent } \\
\text { Municipal } \\
\text { Revenue }\end{array}$ & $\begin{array}{r}\text { of } \\
\text { Tax }\end{array}$ & Average per district \\
\hline A & 7 & $71 \%$ & $10 \%$ \\
\hline B & 5 & $4 \%$ & $1 \%$ \\
\hline C & 11 & $10 \%$ & $1 \%$ \\
\hline D & 19 & $14 \%$ & $1 \%$ \\
\hline D & 56 & $0 \%$ & $0 \%$ \\
\hline Total & 42 & $100 \%$ & $2 \%$ \\
\hline
\end{tabular}

Source: ODI assessment, 2016 with Author's calculations

As shown in this above table very small number of local governments receive customs municipal tax revenue, which creates disparity in local governments budgets. Such local governments with municipal tax revenue from custom posts allocated more funds for basic services of education and health than other comparable local governments. As decentralization continues, the role of local governments in participating basic services provision increases, however, budget disparity among local governments could lead to budget inequality among local governments and consequently the livelihood of the residents.

\subsection{Deficient Mechanism for Intergovernmental Fiscal Transfers}

Inter-governmental funds transfers are largely characterized by many challenges that are widely felt by both local governments and central government institutions. Central government transfers different types of funds to local governments including local governments subsidy, funds for decentralized services of education and health (Service Decentralization Model) which are introduced in number of districts, and Local Development Fund (LDF), of which the latter two are part of Joint Program for Local governance (JPLG).

JPLG program introduced by starting decentralization with Service Delivery Model (SDM) supported by UNICEF where minimum functions of education and health transferred to number of local governments. Keeping business as usual, sector ministries started budgeting allocations to support designated local governments. These funds are under the vote of respective ministries (health and education) However, due to the lack of developed transfer mechanism, the process of transferring fund from vote of respective ministries to local governments goes through long way. Each ministry prepares expenditure warrant to regions of allocated districts, then regional education officer or regional medical officer withdraws funds from regional accountant general through payment voucher where the payee may be regional officer and pays then to respective local government. These redundant processes are time consuming, inefficient, and many times ineffective.

Local authorities claimed irregularities in these including bank deductions and delays where Ministry of Finance claims about tax deductions not returned and lack of financial reports from local governments at all. Interviewed experts stressed that the root cause of such irregularities and inefficiencies to be fragmented system primarily coming from policy and the legal framework.

\subsection{Legal Challenges}

The Constitution of Somaliland provides a framework for a decentralized system of governments. Local governments were given the primary responsibility for service delivery at the local level according to their ability. Mal (2017) concluded there exists poor legislation and capacity problem in local governments. Mohamoud (2012) also pointed out legal conflict regarding ill-defined demarcation of taxes to be collected by local government and central government, and to some extend borders of new districts not defined Legal and regulatory framework were not reviewed based on assessment of local government capacities to deliver functional of service delivery assignment between local governments and central government.

\subsection{Limited Capacity and Transparency}

Financial management practices are below average standard and they use very old fashioned and errorous manuals ( (Mohamoud, 2012). Mayors also showed the challenge of limited skilled staff in local governments. Moreover, sector ministries of health and education have limited capacity in systems and regional offices in particular. The research team found it difficult in finding the financial plans of local governments, the budgets of local governmens 
are not publicly disclosed. It's also currently difficult getting information about work plan and budget for decentralized services of education and health from local governments that shows and clearly indicate how the three different sources of funds are to disbursed (Ministry of education/health, UNICEF, local government).

Elected district authorities to be accountable to local communities/constituents face so many challenges primarily budget constraints and inadequate funding (Ahmed, 2016). However, key respondents in this study thematically reasoned that concerned authorities showed poor leadership quality to use allocated resources to address existing challenges.

\subsection{Conclusion and Recommended Better Ways for Fiscal Decentralization}

\section{1. conclusion}

The number of districts has been increased unnecessarily based on tribal politics. Break-away districts are unable to provide basic services due to their limited taxable economic base and resources mobilization. All grade D districts depend on electoral districts to exercise their voting rights but elected council do not represent them in district council as they have appointed council of mayor, deputy mayor, and executive secretary.

Intergovernmental fiscal transfers are not fairly distributed as they are not based on assessed criteria. Most districts do not get municipal tax revenues which may cause budget disparity among local governments. If decentralization is fully adopted under this situation of revenue inequality among local governments some local governments will end up with relatively smaller local revenue that will more likely have negative future consequences on their livelihoods.

In Somaliland, the democratization is yet clear institutionally set-up and rarely analyzed the impact of macro policies on subnational governments. The fiscal decentralization has not been considered and discussed as a macropolitical level. The Government needs to consider decentralization itself as a reform and choose which modality of decentralization should it go. Districts are characterized by poor public financial management practices which makes them less transparent and less accountable. Therefore, there is a need to reconsider public sector reforms reach local governments and in the near future coordinate the ongoing three reforms in public financial management, decentralization, and civil service. Also, Legal and regulatory framework were not reviewed based on assessment of local government capacities to deliver functional of service delivery assignment between local governments and central government. There is also need to open broader policy debates on functional assignments and budget allocations for local governments to develop comprehensive and blueprint strategic policies and legal framework in fiscal decentralization reform and make a close coordination with other reforms.

\subsection{Recommends for Somaliland's Fiscal Decentralization}

To find well suited coherence of the objectives of decentralization and mechanisms for implementation, this paper recommends to study the design of fiscal decentralization that is contextualized to be consistent with the institutional set up and design government structure. Government shall rethink about planning and implementing policies of subnational governments that solves the proliferated politically appointed districts and then review regulatory framework in terms of assignment of functions and responsibilities between central government and subnational governments. From there, study and design physical and socioeconomic factors that dictate the allocation formula and use of intergovernmental transfers.

Somaliland should decide which type of fiscal decentralization it adopts giving considerate attention to the extent to which local governments autonomy to decide revenue and expenditure allocations, appropriate assignment of expenditure and revenues (tax demarcations) between central governments and local governments should reflect best practices.

For successful implementation fiscal decentralization should be part of comprehensive framework of government but has not to come in isolation (Hobdari et al., 2018). The gradual progress of decentralization must go along with related reforms in strengthening public finance management systems and civil service reforms. With respect to the theories and experience of implemented countries, its strongly recommended that Government expenditures are made as clearly as possible to avoid overlap of resources and challenges in legal mandates arising from duplication of authority and will also likely increase accountability.

\section{References}

Ahmed, Y. J., 2016. Decentralization and Service Delivery in Hargeisa : A case study of Mahmoud Haybe District in Hargeisa City High-quality Research Support programme ( HQRS ) September 2016. Issue September, pp. 1-8.

Alam, M., 2019. Assessment of Fiscal Decentralization in Ethiopia : The Case Study of Selected Basic Sectors of 
Sibu Sire Woreda, East Wollega Zone , Oromia Regional State. 10(2), pp. 124-142.

Anon., 2017. REPUBLIC OF SOMALILAND MINISTRY OF EDUCATION AND HIGHER Education Sector Strategic Plan October 2017. Issue October.

Anon., n.d. Somaliland_Decentralization_Policy_and_Roadmap_Final_-_13_November_2013 (1). s.1.:s.n.

Assefa, D., 2015. Fiscal Decentralization in Ethiopia : Achievements and Challenges. Public Policy and Administration Research, 5(8), pp. 27-40.

Basher, S. A., 2005. Fiscal Decentralization in Developing Countries: A Review of Current Concepts and Practice (review). The Journal of Developing Areas, 37(1), pp. 178-179.

Bernard Dafflon, Thierry Maddies, 2013. The Political Economy of Decentralization in Sub-Saharan Africa; A New Implementation Model in Ghana, Kenya, andSenegal. Washington DC: World Bank.

Bird, R. M., 1995. Fiscal federalism. Issue Gramlich 1987, pp. 151-154.

Defere, G., 2018. A Review of Fiscal Decentralization Practices in Ethiopia. Üniversitepark Bülten, 7(1), pp. 7-13.

Elhiraika, A., 2007. Fiscal Decentralization and Public Service Delivery in South Africa. Issue 58.

Elmi, A. A., 2014. Decentralization Options for Somalia, Mogadishu: Heritage Institute for Policy Studies.

Elmi, A. A., 2015. Decentralized Unitary System : A Possible Middle Ground Model for Somalia. Arab Center for Research and Policy Studies, Issue May.

Faguet, J.-P., 2000. Decentralization and Local Government Performance: Improving Public Service Provision in Bolivia. Revista de Economia del Rosario, 3(1), pp. 127-176.

Garad, A. A., 2017. Poverty Dimensions and People's Perception in Pastoral Areas of Marodijeh Region, Somaliland. Volume 33, pp. 2015-2018.

Haas, A. R., 2017. An Overview of Municipal Finance Hargeisa, Somaliland, Hargeisa: International Growth Center.

Hagmann, T., 2016. Stabilization, Extraversion and Political Settlements in Somalia. s.1.:s.n.

Hartmann, C., 2008. Decentralisation and the Legacy of Protracted Conflict - Mauritius,Namibia and South Africa. In: Decentralisation in Africa. Amsterdam: Amsterdam University Press.

Hidayat, R., 2017. Political devolution: Lessons from a decentralized mode of government in Indonesia. SAGE Open, 7(1).

Hobdari, N., Nguyen, V., Dell'Erba, S. \& Ruggiero, E., 2018. Lessons for Effective Fiscal Decentralization in SubSaharan Africa. s.1.:s.n.

Institute for International Cooperation, 2008. Decentralised Service Delivery in East Africa Institute for International Cooperation. Issue March.

Kim, A.-j., 2019. The Effect of Fiscal Decentralization on the Corruption in Local Governments. The Korean Journal of Local Government Studies, 22(3), pp. 161-188.

Kulipossa, F. P., 2004. Decentralisation and democracy in developing countries: an overview, Development in Practice. Taylor and Francis, pp. 768-779.

Kulipossa, F. P., 2008. Decentralisation and Democracy in Developing Countries: An Overview, Author(s): , published by. Taylor and Fransis.

Mal, A. O., 2017. Local Governance through Decentralization Policy and Institutional Arrangement for Peace , Governance and Service Delivery in Somaliland. 6(8), pp. 2196-2204.

Management, E. \& Management, E., 2013. Joint Program on Local Governance. Issue 1, pp. 1-10.

Martinez-vazquez, J. \& Vaillancourt, F., 2011. Obstacles to Decentralization : Lessons from the Developing World. Decentralization In Developing Countries: Global Perspectives on the Obstacles to Fiscal Devolution, Issue September, pp. 1-13.

Mohamoud, A. A., 2012. Local Governments in Somaliland; Challenges and Opportunities.

Oates, W. E., 2006. On the Theory and Practice of Fiscal Decentralization. Institute for Federalism and Intergovernmental Relations.

Oommen, M. A., 2006. Fiscal Decentralisation to the Sub-State Level Governments. Economic and Political 
Weekly.

Overseas Development Institute, n.d. Fiscal Decentralization Strategy. Hargeisa: s.n.

Person, F. \& Regional, B., 2018. Gateway ID 00096397 Start date January 1. pp. 1-50.

Rossi, E., 2014. Participation and Effective Governance in Somaliland, Hargeisa: Progressio.

Rossi, E., 2017. Participation and Effective Governance in Somaliland Assessment Report. Issue September.

Sato, M., 2002. Intergovernmental transfers, governance structure and fiscal decentralization. Japanese Economic Review, 53(1), pp. 55-76.

Seyoum, G., 1994. Fiscal decentralization and macroeconomic management in Ethiopia. Fiscal decentralization in Ethiopia.

Shamshir, M. et al., 2019. Prevalence of Stunted Growth in Pakistan: A Socio-economic Phenomenon Prevalence of Stunted Growth in Pakistan: A Socio-economic Phenomenon., Darakshan, Phase VI, Defence Housing Authority. 9(6), pp. 9-21.

Shetty, S., Kohad, R., Yeltiwar, R. \& Shetty, K., 2016. Comparative Evaluation of Hydroxyapatite , Potassium Nitrate and Sodium Monofluorophosphate a Desensitising Agents ? A Double Blinded Randomized Controlled Clinical Trial. Oral hygiene and Health, 1(1), pp. 1-11.

Simkin, P., 2016. UN Joint Programme on Local Governance and Decentralized Service Delivery in Somalia, s.1.: s.n.

Smoke, P., 2000. Fiscal Decentralization in East and Southern Africa: A Selective Review of Experience and Thoughts on Moving Forward. ... on Fiscal Decentralization, International Monetary Fund ....

Sullivan, R. S. \& Dutkowsky, D. H., 2013. Public Finance Review. Public Finance Review, 41(1), pp. 144-144.

UNDP, 2013. Joint Program for Local Governance; C2 Annual Progress Report, s.l.: s.n.

Wang, J., 2005. an Empirical Study of Fiscal Decentralization.

Young, A., 2002. An Overview of Intergovernmental Fiscal Relations in Nepal Georgia State. Issue April.

Young, A., 2014. Fiscal Decentralization, Revenue Assignment , And Property Tax In South Georgia State. Issue May.

Yusuf, H. \& Bradbury, M., 2010. Chapter 1 : Public Perception of Local Councils in Somaliland. Issue July 2008. 